\title{
DEVELOPING THRESHOLDS OF POTENTIAL CONCERN FOR INVASIVE ALIEN SPECIES: HYPOTHESES AND CONCEPTS
}

Author:

Llewellyn C. Foxcroft $\mathrm{t}^{1,2}$

\section{Affiliations:}

${ }^{1}$ South African National

Parks, Conservation

Services, South Africa

${ }^{2}$ Centre for Invasion

Biology, Department of

Botany and Zoology,

South Africa

Correspondence to:

Llewellyn C. Foxcroft

e-mail:

llewellynf@sanparks.org

Postal address:

SANParks, Conservation Services, Private Bag X402,

Skukuza, 1350, South

Africa

Keywords:

adaptive management; control; exotic species; objectives hierarchy

Dates:

Received: 04 June 2008

Accepted: 26 Aug. 2008

Published: 27 Mar. 2009

How to cite this article: Foxcroft, L.C., 2009,

'Developing thresholds of potential concern for invasive alien species: Hypotheses and concepts', Koedoe 50(1), Art. \#157, 6 pages. DOI: $10.4102 /$ koedoe.v51i1.157

This article is available at: http://www.koedoe.co.za

(C) 2009. The Authors. Licensee: OpenJournals Publishing. This work is licensed under the Creative Commons Attribution License.

\section{ABSTRACT}

The Kruger National Park (KNP) has developed and refined a system of management called 'strategic adaptive management' (SAM), which rests on the concept of 'threshold of potential concern' (TPC). TPCs represent end-points in a continuum of change. When thresholds are reached - at which point concerns of negative impacts on biodiversity are raised - management options are explicitly considered and implemented. This paper describes the TPCs developed for monitoring and managing invasive alien species (IAS). More importantly, however, it describes the conceptual understanding, principles and hypotheses adopted as the foundations for setting these TPCs. In accordance with adaptive management practices, the TPCs will be revised as the ecological and conceptual understanding of invasions grows and information is gained through research in the KNP and elsewhere.

Conservation Implication: In accepting that species and systems are variable, and that flux is inevitable and desirable, these TPCs developed for invasive alien species specifically, provide end points against which monitoring can be assessed. Once a threshold is reached, the cause of the threshold being exceeded is examined and management interventions recommended.

\section{INTRODUCTION}

New paradigms in ecology stress complex adaptive systems and heterogeneity (Biggs \& Rogers 2003; Pickett, Cadenasso \& Benning 2003). However, embracing a new ecological paradigm requires a new approach to management that accepts and deals sensibly with ecosystem flux. The threshold of potential concern (TPC), as developed by the Kruger National Park (KNP), provides a measurable endpoint in the management paradigm in use in the KNP, namely strategic adaptive management (SAM). SAM is a variation on the widely used concept of adaptive management (Allee 1997; Biggs \& Rogers 2003). However, an important philosophical departure of SAM from standard adaptive management practice is the focus on 'forward' or 'strategic thinking' and predictive assessment. TPCs thus form an important component of SAM, representing goals against which the success of ecosystem management can be measured. Biggs and Rogers (2003) provide a succinct definition of TPCs: 'those upper and lower levels, along a continuum of change in selected environmental indicators that provide the basis for decisions on the acceptability of that change'. The TPC approach allows for fluctuations in the ecosystem but highlights exceedances in ecosystem change over defined space and time scales, thereby defining the desired set of conditions of the system being managed. Thus TPCs, in effect, provide an indication of whether management actions are currently, or preferably, are predicted to in future have an unacceptable impact on biodiversity (biodiversity structure, function and composition; Noss 1990). It is important to note here, however, that the TPCs developed for invasive alien species (IAS) represent only an upper limit (threshold), as the lower threshold implies the absence of alien species.

A central tenet of adaptive management is 'management by experiment' (Rogers 2003). Thus, TPCs form the basis of an inductive approach to SAM, as they are invariably hypotheses of the limits of acceptable change in ecosystem structure, function and composition (Rogers 2003). They are therefore a compatible and well-articulated set of adaptive management end-points (Biggs \& Rogers 2003). As such, their validity and appropriateness are always open to challenge and they must be adaptively modified as understanding and experience of the system being managed increase (Biggs \& Rogers 2003). An important aspect of TPCs is that they are pre-agreed goals, and consensus has thus already been reached on possible sets of future actions once TPCs are reached. This therefore implies that management is prevented from stalling or procrastinating at such point. When a TPC is reached or, preferably, when modelling predicts that it will be reached, it prompts an assessment of the causes of the extent of change (Biggs \& Rogers 2003). In this manner, the exceeded TPC represents 'one dimension of the composite desired envelope represented by all the objectives together' (Biggs \& Rogers 2003).

In providing a detailed description of the current TPCs and their underlying hypotheses, I first describe the KNPs 'management by objectives' approach. I then explore the scientific basis of each TPC and its criteria, providing some ideas for future work and the integration of invasive species impacts into the overall biodiversity TPCs.

\section{DISCUSSION}

\section{Management by objectives}

The KNP management plan is arranged in a series of objectives, cascading down from the higher, coarser level objectives to the lower, ground level goals (Du Toit, Rogers \& Biggs 2003; Foxcroft 2004; Foxcroft \& Downey 2008). The revised objectives provide for a holistic approach to invasive-species management (KNP 2005) and include all alien species. I deliberately use the term 'alien' as opposed to various synonyms, such as 'exotic', due to the potential confusion that they create (Pyšek et al. 2004; Richardson et al. 2000). Alien plants are defined as 'taxa in a given area whose presence there 
is due to intentional or unintentional human involvement, or which have arrived there without the help of people from an area in which they are alien'. Invasive plants are 'a subset of naturalized plants that produce reproductive offspring, often in very large numbers, at considerable distances from the parent plants, and thus have the potential to spread over a large area'. Subsets of invasive species, which change the character, form or function of the ecosystem over a substantial area, are termed 'transformer species' (Pyšek et al. 2004; Richardson et al. 2000).

Placed under the ecosystem objective of the KNP (see KNP 2005), the main aim of the alien impact objective is 'to anticipate, prevent entry and where feasible and/or necessary control IAS in an effort to minimize the impact on, and maintain the integrity of indigenous biodiversity'. For the purposes of the KNP and building on the above-mentioned definition of alien species, 'any species or organisms which have been introduced into, or entered the KNP on its own accord, from outside its borders' are considered alien.

The implication of this is that:

1. any species from outside the boundaries of South Africa is considered alien (except in the case of the Mozambican and Zimbabwean sections of the Transfrontier Conservation Area, which is a natural extension of the KNP ecosystem);

2. any species that may be indigenous to South Africa but that does not occur within the KNP ecosystem is considered alien to the KNP ecosystem; and

3. any species within the KNP that moves from one particular landscape to another where it does not occur naturally is considered alien to that landscape.

Although the list of objectives is described fully in KNP (2005; also see http://www.sanparks.org/parks/kruger/ conservation/scientific/mission/managementplan.php), the five main alien impact objectives are summarised here. These objectives closely follow the principles advocated by international best-management practice standards (Wittenberg \& Cock 2001; 2005):

- Objective 1: Strategy and support: To develop a long-term strategy for the management of IAS by evaluating the current and projected future overall scale of threat, by addressing organisational and infrastructural capacity, by developing policy and by building support for continued high-level commitment.

- Objective 2: Prevention: To anticipate and evaluate imminent or potential risks (the likelihood of invasion and the likely impact of invasion) to the KNP and pathways of invasion and to develop effective mechanisms to monitor, manage or mitigate these.

- Objective 3: Control: To ensure the effective and timely development and implementation of integrated control strategies in such a manner that both rapid response and long-term maintenance goals are met.

- Objective 4: Research: To promote and develop a coordinated research programme to develop a clearer understanding of the dynamics and the impacts of alien-species invasions.

- Objective 5: Awareness: To develop an awareness programme to inform and educate SANParks staff and visitors on especially the dangers and consequences of IAS to facilitate global IAS initiatives.

The current TPCs therefore link directly to the prevention and control objectives in that acceptable limits for the spread of a species are set. The research objectives involve the development of programmes to evaluate the impacts of invasions at various scales and alien-species abundance (density).

\section{Scientific principles for the basis of TPCs}

The principle that the KNP is not an island and is substantially impacted on by actions beyond its borders is a central tenet of the understanding and management of alien-species invasions

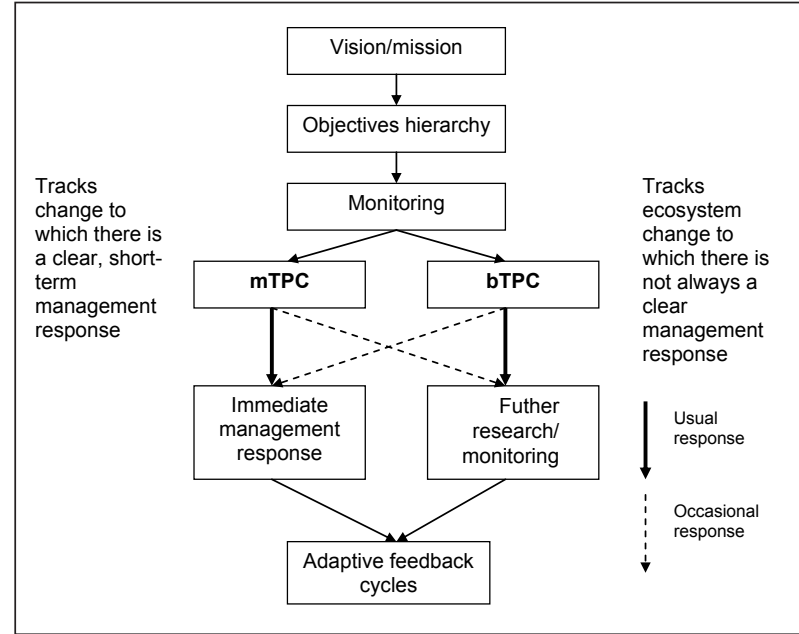

FIGURE 1

Relationship between TPCs aimed at management and TPCs aimed at detecting change in biodiversity or ecosystem function and structure

(Foxcroft, Rouget \& Richardson 2007). Working in concert with this is the acceptance of the role of temporal flux and spatial heterogeneity within the ecosystem (Pickett, Cadenasso \& Benning 2003; Rogers 2003). This needs to be embraced in the context of invasions as well (Foxcroft 2004). Although desirable, the eradication or control of all alien species is neither feasible nor practical. Fluxes in the spread and abundance of alienspecies populations must thus be accepted, even though this is contrary to most alien-species management ideals. Although invasions by alien species are normally considered to be unidirectional in that they progress from an initial founding population to becoming widespread transformer species, this is the exception rather than the rule. Most species, whether naturalised or invasive, fluctuate to some extent depending on drivers, such as rainfall and disturbance. While most managers concerned with alien species strive to eradicate or manage all alien species and to suppress the populations as close to zero as possible, we contend that this approach is not possible either in the KNP or (generally) anywhere else. This is due mainly to the size of the KNP and to the number of species present. We suggest that management will be more effective by focusing its resources on the most problematic species only and in the areas where they are becoming problematic. As long as the species are present at below acceptable thresholds for a determined period, the species should not be a management priority. The TPC system allows for fluctuation, including of alien species, but highlights critical 'turning points' where concern is raised about the possible negative effects of aliens on biodiversity (Foxcroft 2004).

The invasive-species TPCs, while already having undergone revision (Biggs \& Rogers 2003; Foxcroft 2004; Foxcroft \& Downey 2008; Foxcroft \& Richardson 2003; Freitag-Ronaldson \& Foxcroft 2003), do not yet specifically address the direct and measurable negative impacts on biodiversity. The current TPCs instead represent operational or management thresholds of potential concern (mTPCs) (Figure 1). A well-articulated set of mTPCs complements bTPCs by having a short-term, immediate management response to an assumed impact.

The mTPCs follow a conceptual understanding of the process of biological invasions (Richardson et al. 2000) and highlight changes in distribution within and on the KNP boundaries (Figure 2).

The invasion of an alien species into an area follows a general pattern in which the species overcome a series of barriers that impedes the invasion of some species and that results in a smaller subset becoming transformer weeds (Foxcroft, Parsons \& McLoughlin 2008). Each stage in the process presents 


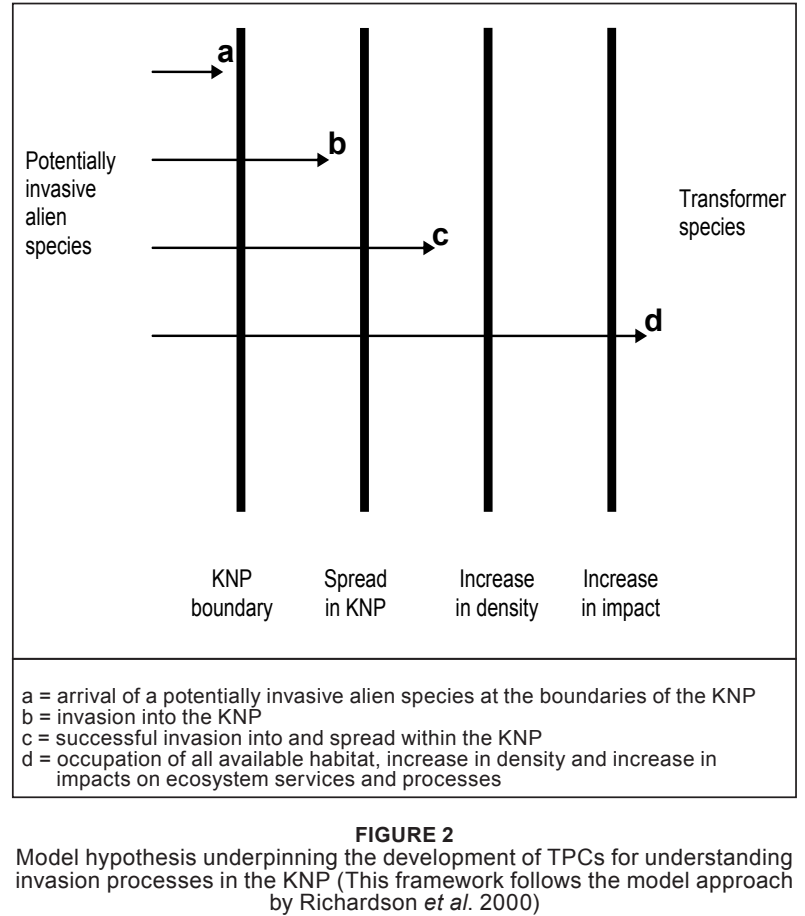

the KNP with a particular threat and suggests appropriate management actions. This therefore means that the thresholds focus on the alien species rather than on their negative impacts on biodiversity. This further means that the negative biodiversity impacts are implied and that the presence of alien species is unacceptable to the biodiversity conservation values of SANParks.

The use of TPCs to raise management concerns does not, however, mean that control operations can now be stopped and carried out only when a TPC is reached. To the contrary: normal management operations aimed at the maintenance of a species at a low abundance or at the containment of a species at its current distribution require ongoing follow-up operations to be successful and are a critical element in the overall control programme. Only at a low abundance (or limited distribution) can we assume that a species is having little impact on the system and can we thus allow the idea of flux in alien-species distribution and abundance. The TPC should highlight only when and where this may be exceeded and should then require specific, targeted action. This may be compared to the management of fire in the KNP. Rangers initiate patch burns as an ongoing management activity (in the same way that alien plants are controlled on an ongoing basis) to achieve appropriate levels of heterogeneity in (among other variables) patch size and fire intensity (in the same way that alien-plant control aims to prevent negative impacts on biodiversity by preventing high abundances of alien plants), which are framed as the various TPCs (Van Wilgen, Govender \& MacFadyen 2008). Exceeding these thresholds results in an assessment of the cause and of appropriate action and perhaps in a change to the management approach.

The first invasive-species TPCs (Foxcroft \& Richardson 2003) provided a list of various criteria for evaluation. These included 1) a new distribution in the KNP or an increase in distribution, 2) an increase in density, 3) the rate of spread versus the rate of clearing, 4) impact on biodiversity and 5) outside alien threats (Foxcroft \& Richardson 2003). Experience, however, highlighted the need to adapt the system due to repeat exceedances of the same TPCs. In other words, the TPC system was not able to deal sensibly with repeat invasions that were no longer cause for the same level of concern. This led to the development of multiple- level TPCs to avoid raising 'false alarms' (Foxcroft 2004) or, in other words, to rationalise them into a series of graded practical challenges that are feasible to handle in practice and that are still meaningful in a conservation ecology sense (see Table 1 for a sample of TPCs exceeded to date and Table 2 online supplementary for the full list).

The main hypothesis behind developing TPCs for IAS is that alien species represent a threat to the biodiversity of the KNP and that, if left unmanaged, will cause substantial - often irreversible - biodiversity or economic loss (McNeely et al. 2001; Mooney et al. 2005; Pimentel et al. 2005). The principles adopted for the development of these mTPCs are further captured in the 'barriers' model by Richardson et al. (2000). Using this approach, the 'points of concern' are reflected as the barriers to invasion and the next level of TPC is invoked to overcome the barriers (Figure 2). As a species approaches the KNP, management's response is to prevent this introduction (point a in Figure 2). This entails, where possible, the KNP controlling the population itself, partnering with institutions such as provincial alien-clearing projects (Working for Water, for example, which is a national programme that aims to control alien plants to prevent impacts on water resources, economic and social impacts and impacts on biodiversity; see also Van Wilgen, Le Maitre \& Cowling 1998) or entering into cooperative agreements with landowners. Once the species has invaded the KNP, the spread of the species is examined against the next level of TPC, where eradication (if possible) or containment strategies are called into force (point $\mathbf{b}$ ). There may, however, be examples where the tabling of a TPC (formally recording the exceedance of a TPC and placing it on the management agenda; see also Foxcroft \& Downey 2008) leads to a well considered 'do nothing' option. Theoretically, the third level of TPC is invoked once all available habitat has been invaded. At this point, the main concern is the abundance of the species (point c). Although a species may not have expanded its range to include the entire available habitat in the KNP, however, it is assumed that, at a local scale, patches have reached a density that may have some level of impact on biodiversity (its composition or function) in that particular area (point d).

Although all the TPCs are nested within the framework outlined above, the following section discusses the hypotheses and theory behind each TPC criterion.

\section{Level 1 TPCs}

TPCs that deal with new invasions of a species in the KNP (Figure 3a).

\section{Criteria:}

- Imminent external threat (a species on the park boundaries which is believed by most experts to be able to invade within 12 months).

- First-ever record in the KNP

\section{Principles:}

1. The introduction of any new alien species is contrary to the mandate of SANParks (Foxcroft, 2006; KNP, 2005).

2. The potential negative impacts of biological invasions far outweigh the risk that the alien species will be benign (see, for example, Mooney et al. 2005 and the numerous references therein).

3. A 12-month period of likely entry into the KNP provides sufficient time to develop management strategies and control the population appropriately outside the KNP. This should, however, be considered per species and adjusted accordingly where necessary.

\section{Level 2 TPCs}

TPCs that deal with an increase in the distribution of a species (or of all species combined) in the KNP over a 12-month period (Figure 3b). 
TABLE 1

Sample of alien species TPC exceedances to date

\begin{tabular}{llllll}
\hline DATE & $\begin{array}{l}\text { TPC } \\
\text { LEVEL* }\end{array}$ & TPC DETAIL & $\begin{array}{l}\text { SPECIES OF } \\
\text { CONCERN }\end{array}$ & MANAGEMENT RESPONSE & $\begin{array}{l}\text { EXPECTED OUTCOME AT THE TIME OF THE TPC } \\
\text { NOTIFICATION AND CURRENT STATUS }\end{array}$ \\
\hline Oct. 1999 & $\begin{array}{l}\text { Multi-level } \\
\text { TPCs not in } \\
\text { use }\end{array}$ & $\begin{array}{l}\text { Imminent outside threat the KNP (Crocodile } \\
\text { River) }\end{array}$ & $\begin{array}{l}\text { Chromolaena odorata } \\
\text { (Chromolaena) }\end{array}$ & $\begin{array}{l}\text { Special Working for Water contract } \\
\text { issued to have the localised patch of } \\
\text { plants eradicated }\end{array}$ & $\begin{array}{l}\text { The aim was to eradicate the patch of plants but it soon became } \\
\text { evident that it could not be completely removed and it therefore } \\
\text { became part of a long-term, ongoing management programme }\end{array}$ \\
Sept. 20072 & $\begin{array}{l}\text { First-ever records in a } \\
\text { new grid cell (Olifants } \\
\text { River) }\end{array}$ & $\begin{array}{l}\text { Opuntia stricta (sour } \\
\text { prickly pear) }\end{array}$ & $\begin{array}{l}\text { Chemical control and surveys to } \\
\text { determine whether the plants have } \\
\text { already spread }\end{array}$ & $\begin{array}{l}\text { The eradication of the patches of plants but long-term monitoring } \\
\text { for regrowth and re-invasion from sources in the upper Olifants } \\
\text { River catchment }\end{array}$ \\
\hline
\end{tabular}

*Level 2: TPCs that deal with an increase in the distribution of a species (or of all species combined) in the KNP over a 12-month period

Criteria:

- First-ever record from a new grid cell.

- Any new grid cell invaded that is not contiguous with the previous distribution.

- The expansion of invasive species through contiguous grid cells representing more than a $5 \%$ increase over the number of grid cells recorded as invaded in the reference (base) year.

Principles:

1. The early detection of new incursions of invasive species allows timely response and potential for eradication. This principle is widely accepted (Wittenberg \& Cock 2001; 2005) as a standard procedure for the successful control of invasions. Studies further suggest that, once an invasion has increased to an area of over $100 \mathrm{ha}$, the chances for eradiation are minimal (Rejmánek \& Pitcairn 2002). The increase of propagule pressure reaches a critical mass at some stage, at which point management is compromised. This is based on the 'long-fuse, big bang' theory, which states that, although a build-up of alien species may initially be slow, it is followed by a rapid and exponential increase in the population and propagative individuals and is seldom manageable once this point is reached (Chapman, Le Maitre \& Richardson 2001; Wilkinson 1995).

2. The eradication of newly formed invasion foci increases the probability of the invasion being contained at its current extent (Moody \& Mack 1988). Although the criteria stated above were already determined in the first iteration of alienspecies TPCs, only the first ever record from a new grid cell/area' TPC was used.

3. Although the expansion and contraction of alien species are expected to occur through natural processes and disturbances, such as floods, droughts and the resulting change in succession (the acceptance of a flux paradigm), the total area of the invasion should not be allowed to increase above a stated maximum tolerable 'ceiling' level from the base scenario. This level is currently set at $5 \%$ but it is an estimate and requires refinement.

\section{Level 3 TPCs}

TPCs that deal with an increase in the density of a species (or of overall alien-species density) in the KNP (Figure $3 \mathrm{c}$ and d). These TPCs are not yet operational, however, due to the lack of data and an efficient cost-effective monitoring option to date. They are nonetheless described hypothetically and may have the potential to be used as surrogates for biodiversity impact TPCs in future if research is able to relate species abundance to unacceptable impacts.

Criteria:

- Any increase by two or more density classes in any grid cell.

- Any increase of one density class upwards of 'medium density' in any grid cell.

Density (or apparent density) is currently measured in the following classes but will be reviewed as monitoring options are evaluated (Le Maitre \& Versfeld 1994):

- Rare: The plants are present but at very low densities, occurring here and there; density $=0.01 \%$

- Occasional: The plants are widely spaced, occurring here and there, on average, more than 10 canopy covers apart; density $=0.02-1 \%$ a) Level 1 TPC

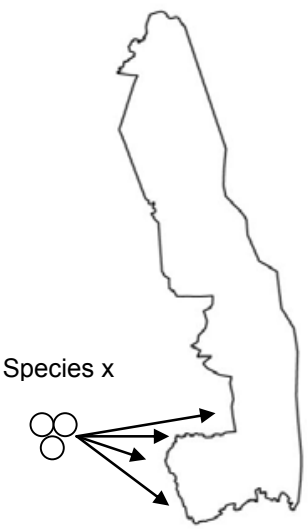

b) Level 2

TPC

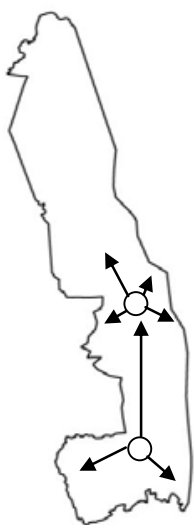

c) Level 3 TPC

\section{d) Level 3 TPC \\ (hypothetical)}
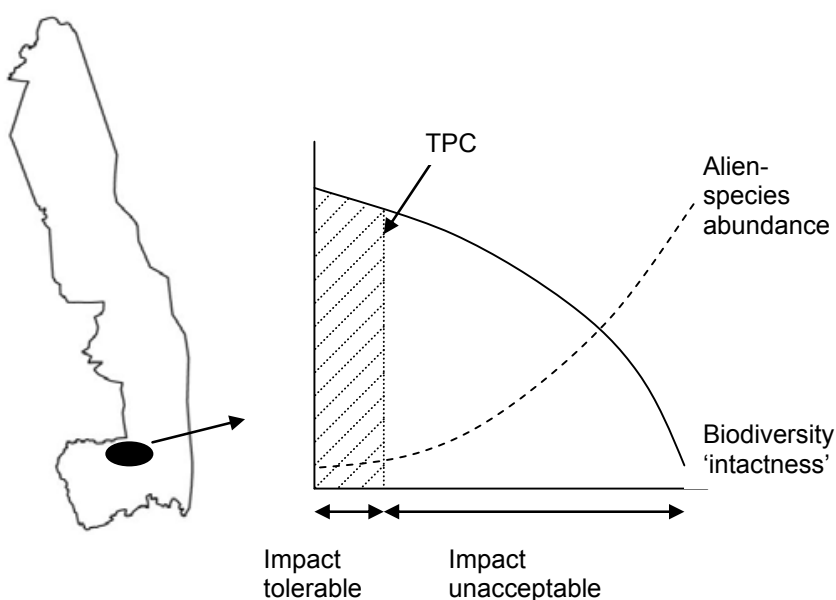

In a), species $x$ represents an imminent external threat to the KNP. In b), the species could not be prevented from entering the KNP; no further TPCs are therefore raised due to repeat introductions and, instead, level 2 TPCs are raised once the species spreads beyond its current distribution. In c), a species may be locally dense and needs to be monitored to ensure that it does not exceed the predefined density limit d), at which point negative biodiversity impacts (a decrease in biodiversity intactness) are expected 
- Very scattered: The plants average 3 to 10 canopy diameters apart; density $=1.1-5 \%$

- Scattered: The plants average 1 to 3 canopy diameters apart; density $=5.1-25 \%$

- Medium: There are clear and plenty of gaps between the canopies of the plants, and other vegetation is still present and vigorous, the plants averaging 0.3 to 1 canopy diameters apart; density $=25.1-50 \%$

- Dense: There are small gaps between the canopies of the plants, there is no canopy overlap and other vegetation is still present, the plants averaging 0.1 to 0.3 canopy diameters apart; density $=50.1-75 \%$

- Closed: The canopies of the plants are closed, touching or overlapping, and other vegetation is generally suppressed, sparse or lacking, the plants averaging less than 0.1 canopy diameters apart; density $>75 \%$

\section{Hypothesis:}

An increase in the density of invasive species leads to a negative impact on indigenous biodiversity, whether in terms of composition, function or structure. This hypothesis has not, however, been tested in the KNP and only arbitrary density values have been assigned as evaluation criteria thus far.

\section{Future work}

In order to detect changes in distribution or abundance, a spatially explicit dataset with reasonable coverage is required to set the baseline from where changes can be evaluated. This is a substantial challenge for an area the size of the KNP (which is approximately $20,000 \mathrm{~km}^{2}$ in extent). The KNP has fortunately, however, been developing a spatially explicit dataset that covers the KNP and that contains about 28,000 data points (Foxcroft 2008b). This has been possible due largely to the use of CyberTracker units (handheld PDA/GPS devices with customised software), which are deployed daily by rangers during their patrols (Foxcroft 2008b). Due to the extent of the area that needs to be covered, however, it is believed that the data will be representative of the real levels of invasion only by about 2009/2010, from when changes can then be plotted. This will require the problem of the scale at which change in species distribution is detected being resolved (Foxcroft 2008b). Once this has been done, all species records can then be assigned to a grid cell and the data of subsequent years can be overlaid on the base year, allowing the TPC criteria to be assessed.

This, however, deals only with the TPCs that evaluate spatial distribution. The level 3 TPCs, which deal with change in the abundance of species, require further work 1) to develop a monitoring programme that provides the necessary data to evaluate these TPCs and 2) to be able to relate particular abundances to negative impacts on biodiversity. From this, we can develop new 'biodiversity impact' or biodiversity thresholds of potential concern (bTPCs) that either directly or through the use of appropriate surrogates address the issue of the negative impacts of alien species on biodiversity. These would ultimately replace the currently used level 1 and 2 TPCs. This was highlighted in the alien-impact section of the objectives hierarchy as an important avenue of future research (KNP 2005). A start on this has already been made through research that aims to quantify impacts on selected biodiversity indicators, such as the impact of Opuntia stricta (the sour prickly pear) on spiders and beetles as indicator species. It clearly still needs to be expanded, however, to measure impacts on other ecosystem components, such as ecosystem services and provisions, and for other alien species. Useful studies have been done on the water-use impacts of invasive-plant species and on various land-use practices (such as commercial forestry using alien trees; for examples, see Le Maitre, Versfeld \& Chapman 2000; Le Maitre et al. 2001; Versfeld, Le Maitre \& Chapman 1998). We also need to develop the ability to express impacts in terms of biodiversity loss due to alien species in the KNP system.

\section{CONCLUSION}

The development of TPCs for the management of invasive species presents an approach to management that is fundamentally proactive in nature. The system allows for ecosystem flux but within predefined thresholds of acceptability. Although the current TPCs represent a pragmatic approach to a substantial biodiversity concern (that of IAS) over a vast area, further development is needed. Ideally, TPCs need to be developed that highlight the point at which IAS present a measurable threat to the biodiversity composition, function or structure of an area.

\section{ACKNOWLEDGEMENTS}

I am greatly indebted to many of my colleagues (especially to Stefanie Freitag-Ronaldson and Harry Biggs) for stimulating discussion and advice.

Our sincerest appreciation to Robert J. Scholes who was the responsible editor for this article.

\section{REFERENCES}

Allee, V., 1997, The knowledge evolution: Expanding organisational intelligence, Butterworth-Heinemann, Newton.

Biggs, H.C. \& Rogers, K.H., 2003, 'An adaptive system to link science, monitoring and management in practice', in J.T. Du Toit, K.H. Rogers \& H.C. Biggs (eds.), The Kruger experience: Ecology and management of savanna heterogeneity, pp. 59-80, Island Press, Washington.

Chapman, R.A., Le Maitre, D.C. \& Richardson, D.M., 2001, 'Scenario planning: Understanding and managing biological invasions in South Africa', in J.A. McNeely (ed.), The great reshuffling: Human dimensions of invasive alien species, pp. 195208, IUCN, Cambridge.

Du Toit, J.T., Rogers, K.H. \& Biggs, H.C. (eds.), 2003, The Kruger experience: Ecology and management of savanna heterogeneity, Island Press, Washington.

Foxcroft, L.C., 2004, 'An adaptive management framework for linking science and management of invasive alien plants', Weed Technology 18, 1275-1277.

Foxcroft, L.C., 2006, 'Alien species in Kruger National Park', Unpublished policy document, Version 2, South African National Parks.

Foxcroft, L.C. \& Downey, P.O., 2008, 'Protecting biodiversity by managing alien plants in national parks: Perspectives from South Africa and Australia', in B. Tokarska-Guzik, J.H. Brock, G. Brundu, L. Child, C.C. Daehler \& P. Pyšek (eds.), Plant invasions: Human perception, ecological impacts and management, pp. 387-403, Backhuys Publishers, Leiden.

Foxcroft, L.C., Parsons, M., McLoughlin, C.A. \& Richardson, D.M., 2008a, 'Patterns of alien plant distribution in a river landscape following an extreme flood', South African Journal of Botany 74, 463-475.

Foxcroft, L.C. \& Richardson, D.M., 2003, 'Managing alien plant invasions in the Kruger National Park, South Africa', in L.E. Child, J.H. Brock, G. Brundu, K. Prach, P. Pyšek, P.M. Wade et al. (eds.), Plant invasions: Ecological threats and management solutions, pp. 385-403, Backhuys Publishers, Leiden.

Foxcroft, L.C., Richardson, D.M., Rouget, M. \& MacFadyen, S., 2008b (in press), 'Patterns of alien plant distribution at multiple spatial scales in a large national park: Implications for ecology, management and monitoring', Diversity and Distributions.

Foxcroft, L.C., Rouget, M. \& Richardson, D.M., 2007, 'Risk assessment of riparian plant invasions into protected areas', Conservation Biology 21, 412-421.

Freitag-Ronaldson, S. (ed.), 2005, Revision of the management plan for the Kruger National Park, Part 1: Objectives hierarchy, South African National Parks, Skukuza.

Freitag-Ronaldson, S. \& Foxcroft, L.C., 2003, 'Anthropogenic influences at the ecosystem level', in J.T. Du Toit, K.H. Rogers \& H.C. Biggs (eds.), The Kruger experience: Ecology and management of savanna heterogeneity, pp. 391-421, Island Press, Washington. 
Le Maitre, D.C., Van Wilgen, B.W., Gelderblom, C.M., Bailey, C., Chapman, R.A. \& Nel, J.A., 2002, 'Invasive alien trees and water resources in South Africa: Case studies of the costs and benefits of management', Forest Ecology and Management 160(3), 1-17.

Le Maitre, D.C. \& Versfeld, D.B., 1994, Field manual for mapping populations of invasive plants for use with the catchment management system, CSIR, Jonkershoek.

Le Maitre, D.C., Versfeld, D.B. \& Chapman, R.A., 2000, 'The impact of invading alien plants on surface water resources in South Africa: A preliminary assessment', Water South Africa 26, 397-408.

McNeely, J.A., Mooney, H.A., Neville, L.E., Schei, P.J. \& Waage, J.W., (eds.), 2001, Global strategy on invasive alien species, IUCN, Cambridge.

Mooney, H. A., Mack, R., McNeely, J., Neville, L., Schei, P. \& Waage, J., 1988, 'Controlling the spread of plant invasions: The importance of nascent foci', Journal of Applied Ecology 25, 1009-1029.

Mooney, H. A., Mack, R., McNeely, J., Neville, L., Schei, P. \& Waage, J., (eds.), 2005, Invasive alien species: A new synthesis, Island Press, Washington.

Noss, R.F., 1990, 'Indicators for monitoring biodiversity: A hierarchical approach', Conservation Biology 4, 355-364.

Pickett, S.T.A., Cadenasso, M.L. \& Benning, T.L., 2003, 'Biotic and abiotic variability as key determinants of savanna heterogeneity at multiple spatiotemporal scales', in J.T. Du Toit, K.H. Rogers \& H.C. Biggs (eds.), The Kruger experience: Ecology and management of savanna heterogeneity, pp. 22-40, Island Press, Washington.

Pimentel, D., Zuniga, R. \& Morrison, D., 2005, 'Update on the environmental and economic costs associated with alieninvasive species in the United States', Ecological Economics $52,273-288$.

Pyšek, P., Richardson, D.M., Rejmánek, M., Webster, G.L., Williamson, M. \& Kirschner, J., 2004, 'Alien plants in checklists and floras: Towards better communication between taxonomists and ecologists', Taxon 53, 131-143.
Rejmánek, M. \& Pitcairn, M.J., 2002, 'When is eradication of exotic pest plants a realistic goal?', in C.R. Veitch \& M.N. Clout (eds.), Turning the tide: The eradication of invasive species, pp. 249-253, IUCN, Cambridge.

Richardson, D.M., Pyšek, P., Rejmánek, M., Barbour, M.G., Panetta, F.D. \& West, C.J., 2000, 'Naturalization and invasion of alien plants - concepts and definitions', Diversity and Distributions 6, 93-107.

Rogers, K.H., 2003, 'Adopting a heterogeneity paradigm: Implications for management of protected savannas', in J.T. Du Toit, K.H. Rogers \& H.C. Biggs (eds.), The Kruger experience: Ecology and management of savanna heterogeneity, pp. 41-58, Island Press, Washington.

Van Wilgen, B.W., Govender, N. \& MacFadyen, S., 2008, 'An assessment of the implementation and outcomes of recent changes to fire management in the Kruger National Park', Koedoe 50(1), 22-31.

Van Wilgen, B.W., Le Maitre, D.C. \& Cowling, R.M., 1998, 'Ecosystem services, efficiency, sustainability and equity: South Africa's Working for Water programme', Trends in Ecology and Evolution 13(9), 378.

Versfeld, D.B., Le Maitre, D.C. \& Chapman, R.A., 1998, Alien invading plants and water resources in South Africa: A preliminary assessment. CSIR, Division of Water, Environment and Forestry Technology, WRC Report No. TT 99/98 CSIR No. ENV/S-C 97154, Stellenbosch.

Wilkinson, L., 1995, 'How to build scenarios: Planning for long fuse, big bang problems in an era of uncertainty', Wired special edition: Scenarios: The future of the future, 15 September, pp. 74-81.

Wittenberg, R. \& Cock, M.J.W. (eds.), 2001, Invasive alien species: A toolkit of best prevention and management practices, $\mathrm{CAB}$ International, Oxon.

Wittenberg, R. \& Cock, M.J.W., 2005, 'Best practices for the prevention and management of invasive alien species', in H.A. Mooney, R.N. Mack, J.A. McNeely, L.E. Neville, P.J. Schei \& J.K. Waage (eds.), Invasive alien species: A new synthesis SCOPE: 63, pp. 209-232, Island Press, Washington. 